\title{
Linguistics, Religion and Law in Colonial New South Wales: Lancelot Threlkeld and Settler-Colonial Humanitarian Debates
}

\author{
Anna Johnston
}

Reverend Lancelot Threlkeld was a familiar face in the Sydney law courts during the late 1820s and 1830s. The missionary - the sole London Missionary Society (LMS) representative in the Australian colonies during this period was regularly accompanied by an Aboriginal man, Biraban, who served as dual translator and advisor to Threlkeld. The presence of the two men dramatised questions about Aboriginal legal status and humanitarian interests in the colonial legal system, connecting local affairs with broader imperial concerns. Attending many of the key cases during the 1830s, Threlkeld was instrumental in raising uncomfortable questions about how legal processes dealt with Aboriginal people. His prolific and provocative writing on such issues circulated settler colonial controversies pertaining to the law around the British empire. Neither simply a cross-cultural hero nor a self-aggrandising bigot, Threlkeld exemplifies the complexity of settler identities and societies in formation.

In recent years, studies of settler societies have come to the fore in a variety of interdisciplinary contexts, as historians, sociologists, and literary/cultural theorists seek to account for Anglo-American hegemony from the nineteenth century onwards, and to question the self-congratulatory narratives that settler nations typically promulgate about their origins. Legal questions are particularly interesting ones to pose in this context, because they provide a fascinating framework through which to explore the circulation of ideas and discourse related to race, identity, and colonialism. Jennifer Hamilton argues that modern Anglo-American systems of law were significantly influenced by settler encounters with indigenous peoples. How law courts understood indigenous people - whether their ethnic identity was recognised by the court or not, and when and how that identity counted - was central not only to establishing relationships between settlers and indigenes, but also to the very formation of both those identities. In the western United States and Canada, Hamilton suggests, law was central to colonising projects and it had effects beyond legal institutions: these colonial legacies 'are key discursive elements in 
social and political life in settler states'. ${ }^{1}$ Problems of communication continue to trouble twenty-first-century Australian courts, particularly in relation to the provision of interpreting services and, because of the prevalence of ear disease and hearing loss in Aboriginal communities, assistance for defendants with profound speech and hearing disabilities. In these current debates, we can hear echoes of the colonial courts in trying to account for Indigenous difference and in assessing the role of non-Indigenous intermediaries in accessing justice. ${ }^{2}$

The mutually constitutive nature of these relationships — in which not only Indigenous identities but also settler identities were forged (in part) in terms of legal rights and responsibilities - is particularly instructive in historicising contemporary relationships between settler and Indigenous Australians, and between Aborigines and the law. Accounting for the complexity and contradiction within those relationships also attempts 'to make the past less predictable'. ${ }^{3}$ Threlkeld's role as translator in the nineteenth-century courts and more broadly in the colonial community - effectively worked to provide Aboriginal defendants with a way to have their voices heard within a system that struggled to account for them as legal subjects. Yet, in his legal work, Threlkeld also crafted a position for himself that was dependent on his exclusive right to speak on behalf of Aborigines: his translation of Aboriginal evidence about crime was almost always contextualised by his adamant testimony that Indigenous people were incapable of swearing oaths, understanding a higher being (by which they could have sworn), or being converted to Christianity. His conflicted position both enabled and limited Indigenous legal subjectivity. Threlkeld's well-meaning interventions provide a lens through which to examine how white colonists' legal rights and responsibilities (and indeed, their roles within a courtroom) were formed often in conflict with, or contrast to, Indigenous entitlements, in ways that were crucial to settler identity formation.

Threlkeld's Lake Macquarie Mission was one of the LMS's unsuccessful colonial ventures: within two years of its commencement, the society refused to endorse Threlkeld's bills and, in 1829, he was dismissed. ${ }^{4}$ Nevertheless, and with funding from the colonial government (until 1841), Threlkeld persisted and continued to pursue not only evangelising but also two interlinked projects about which he

\footnotetext{
1 Jennifer A. Hamilton, Indigeneity in the Courtroom: Law, Culture, and the Production of Difference in North American Courts (New York and London: Routledge, 2009), 2.

2 See Damien Howard, Sue Quinn, Jenny Blokland and Martin Flynn, 'Aboriginal Hearing Loss and the Criminal Justice System', Aboriginal Law Bulletin 58 (1993), online; 'Specific Hearing Health Issues Affecting Indigenous Australians', in Hear Us: Inquiry into Hearing Health in Australia, Community Affairs References Committee, http://www.aph.gov.au/senate/committee/clac_ctte/hearing_health/report/index.htm accessed 18 October 2011.

3 Nicholas Thomas, 'Against Heritage: An Afterword', in Reading Robinson: Companion Essays to Friendly Mission, eds, Anna Johnston and Mitchell Rolls (Hobart: Quintus, 2008), 187.

4 This chapter draws on research material that is discussed in greater detail in my recent book The Paper War: Morality, Print Culture, and Power in Colonial New South Wales (Crawley: UWAP, 2011).
} 
was passionate: collecting Aboriginal language and translating for Aborigines called before the court. Threlkeld's linguistic skills were a central part of his LMS inheritance: language collection, in order to translate scripture and preach in local languages, was fundamental to Protestant mission work. Experience in Polynesia, prior to his arrival in New South Wales in 1824, ensured that Threlkeld quickly began recording the Aboriginal language that surrounded him at Lake Macquarie. ${ }^{5}$ His first linguistic efforts were collated in 1825, and his major publications appeared intermittently between 1834 and 1850 . Posthumously, his individual works were published as An Australian Language as Spoken by the Awabakal ... (1892). This was not simply an intellectual project. Threlkeld saw his language facility as crucial in intervening between Aborigines and the colonial courts. In this work, as in other arenas, the missionary chose a controversial position that placed him directly at odds with many powerful settler colonial interests. He had written to the LMS in 1825 that, although his appointment was initially to minister to settlers and Aborigines, he could not represent both parties: 'No man, who comes to this Colony and has ground and cattle and Corn, can dispassionately view the subject of the blacks, their interest says annihilate the race' ${ }^{6}$ Threlkeld chose to represent Indigenous interests and his earliest letters to the LMS resound with news of unreported and unprosecuted violence against Aborigines.

Much recent colonial legal history focuses on the period from the 1820s up to the late 1830s and a series of important cases that show the legal system grappling with the question of Aboriginal legal rights and responsibilities. ${ }^{7}$ Threlkeld attended, participated in, or was discussed during many of these cases. From his first appearance in 1827 for $R v$ Tommy, Threlkeld appeared at 11 subsequent trials in the next decade, including the multiple Brisbane Water trials in 1835 and the important inter se case $R v$ Murrell (1836). In his annual Report of the Mission to the Aborigines at Lake Macquarie, New South Wales, Threlkeld regularly discussed matters pertaining to Aboriginal negotiations with the colonial courts, becoming increasingly frustrated with the anomalous position in which Indigenous people found themselves and, eventually, explicitly calling for imperial intervention for humanitarian ends. In written accounts of his court work, Threlkeld explicitly and politically advocated for Aboriginal civil rights. The contradictions between Threlkeld's role within the

\footnotetext{
5 For a comparison of Threlkeld's service in Polynesia and Australia, see Anna Johnston, 'A Blister on the Imperial Antipodes: Lancelot Edward Threlkeld in Polynesia and Australia', in Colonial Lives across the British Empire, eds, David Lambert and Alan Lester (Cambridge University Press, 2006), 58-87.

6 L.E. Threlkeld to Rev. George Burder and W.A. Hankey, 10 August 1826, 'Letter', Council for World Mission (CWM), Australia Box 2, School of Oriental and African Studies (SOAS).

7 Amongst others, see Lisa Ford, Settler Sovereignty: Jurisdiction and Indigenous People in America and Australia, 1788-1836 (Cambridge, Mass., and London: Harvard University Press, 2010); Bruce Kercher, Outsiders: Tales from the Supreme Court of NSW, 1824-1836 (Melbourne: Australian Scholarly Publishing, 2006).
} 
court - as recorded in the court reports appearing in local newspapers - and his written representations about that role reveal the complex and contradictory position he occupied.

Language collection preoccupied Threlkeld from his earliest days in New South Wales. ${ }^{8}$ From his arrival in Newcastle, waiting for a road and a dwelling to be built at Lake Macquarie, Threlkeld erected a tent that Chief Justice Francis Forbes had donated, and conducted interviews with local Aborigines. Forbes's gift reveals the interconnections between linguistics and law from the outset. The missionary sent Forbes a copy of his first printed language study, Specimens of a Dialect of the Aborigines of New South Wales: Being the First Attempt to Form their Speech into a Written Language (1827), and the judge was delighted that his 'very humble contribution ... has derived a value from the work performed beneath its shelter which nothing else could have given it'. ${ }^{9}$ Like other legal men in the colony, Forbes was very interested in Threlkeld's linguistic work and wanted to provide assistance to him. Arguably, this was in part due to the empire-wide interest in collecting indigenous languages - as the century proceeded, language study became something of a gentlemanly pursuit, akin to the burgeoning interest in amateur natural history - but also because there were obvious implications for the colonial legal system in establishing effective formal modes of communication between settlers and indigenes. Men such as Forbes did not operate in a vacuum - his previous experience in Bermuda and Newfoundland clearly informed his New South Wales tenure - and questions about indigenous subjects in colonial law were formulated in transnational and comparative contexts. The shared interest also reveals the imbrication of legal and religious identities in this period.

During his tenure as New South Wales attorney-general, Saxe Bannister regularly corresponded with and sought information from Threlkeld; the two men arrived in Sydney within months of each other in 1824. The connection was instrumental for Threlkeld: Bannister solicited his social calls, introduced him to the newly arrived governor Lieutenant-General Ralph Darling and Archdeacon Thomas Hobbes Scott, and regularly sought his opinion on current affairs. Bannister was fascinated by the missionary's linguistic project, regularly enquiring about and commenting upon Threlkeld's methods. Threlkeld wrote to him frankly, in 1825:

With respect to seeing my system, it can be seen and known in two minutes, namely, first obtain the language, then preach the Gospel,

8 For an excellent overview of Threlkeld's linguistic work, see David A. Roberts, “'language to save the innocent": Reverend L. Threlkeld's Linguistic Mission', Journal of the Royal Australian Historical Society 94, no. 2 (2008): 107-25.

9 Niel Gunson, ed., Australian Reminiscences and Papers of L.E. Threlkeld, Missionary to the Aborigines, 1824-1859 (Canberra: AIAS, 1974), quoted at 229. 
then urge them from Gospel motives to be industrious at the same time becoming a servant to them to win them to that which is right. This is the sum and substance of our practice. We persuade Men. ${ }^{10}$

Bannister's education lent him insight into linguistic study. On reading his personal manuscript copy of Threlkeld's first linguistic work, An Orthography and Orthoepy of a Dialect of the Aborigines of New South Wales Part 1 (1825), Bannister warmly congratulated the author, asked for extra copies to send to friends in London and Oxford, and recommended that the LMS should send a copy to Lord Bathurst (then colonial secretary) in order to shore up the approval of the New South Wales land grant for the mission. Although supportive, he clearly questioned some of Threlkeld's methodology and, in so doing, revealed his assessment of Aboriginal capabilities:

I have always thought that the greatest care should be taken not to apply the complications of grammar as established in books to the expressions of a simple people - and perhaps your present pursuit, if confined rightly to an examination of the mere actual modes of speech in use here by the uncorrupted, will exhibit a very curious and instructive stage of the human mind. ${ }^{11}$

Despite his reservations about the sophistication of Aboriginal languages, Bannister directly solicited Threlkeld's assistance for the new court system established in 1824. Threlkeld declined Bannister's request to train interpreters for the courts in 1826 as he felt his linguistic knowledge was not yet adequate.

The following year, Bannister was replaced as attorney-general by Alexander Macduff Baxter, and Threlkeld was directed to attend $R v$ Tommy as an interpreter: he demurred 'on account of my little knowledge of the language' but was told that he would have Bungaree, probably one of the best-known Aboriginal figures in Sydney at the time, to assist and that he must 'do [his] best'. ${ }^{12}$ Baxter's enlistment of Bungaree was largely symbolic, and his placatory words either naive or cynical. Unless able to prove that they understood English and had a belief in a higher being in order to demonstrate the meaning of an oath, Aborigines were not able to be sworn as witnesses; neither, as Threlkeld and Biraban repeatedly found, could Aboriginal advisors be sworn as official translators. Without an acceptable translator who could swear an oath, Aboriginal voices were effectively silenced by the legal system. Men such as Bungaree and Biraban were crucial to the communicative acts taking place between the missionary and defendants - their role as cultural and legal

10 L.E. Threlkeld to Rev. George Burder, 10 October 1825, CWM, Australia Box 2, SOAS.

11 L.E. Threlkeld to Rev. George Burder, 22 October 1825, CWM, Australia Box 2, SOAS, quoting Bannister.

12 L.E. Threlkeld, 'Memoranda of Events at Lake Macquarie: Journal Extracts and Annual Reports to 1841', in Gunson, 97. 
intermediaries is highly suggestive and would bear further analysis than is possible here. Sometimes Biraban needed a second intermediary to assist his advice to Threlkeld. In 1837, in $R v$ Wombarty, Biraban found a Port Macquarie man who could communicate with the accused (who was from the interior near Port Macquarie') but because 'the Black could not be sworn with myself as assistant interpreter' Wombarty was discharged. ${ }^{13}$ These moments in court represent very complex cross-cultural negotiations. Even though the records are partial (and often problematic in their bias), the glimpses that we can reconstruct reveal just how nuanced and troubled was the contemporary debate.

Threlkeld's first court appearance was unprepossessing: neither he nor Bungaree succeeded in communicating with the Aboriginal defendant Tommy, who made his defence in his own language with rare phrases of broken English. Neither Bungaree nor Threlkeld seem to have had a working knowledge of that language, which presumably pertained to the Bathurst region where the alleged crime occurred: despite his linguistic study, Threlkeld (like many others) was slow to realise that separate regional languages existed which could be mutually incomprehensible. Forbes, the presiding judge, is reported in the Sydney Monitor as summarising the case as 'fully made out'; and the jury found Tommy guilty. ${ }^{14} \mathrm{He}$ was sentenced to death and was hanged on the last day of 1827. Threlkeld declared that Tommy was 'found guilty on the clearest evidence', ${ }^{15}$ and attended the execution as part of the religious presence that commonly accompanied condemned men. Threlkeld's attendance subsequently generated an unbecoming spat between Protestant and Catholic clergy in the colonial newspapers - Tommy's Catholic baptism on the scaffold infuriated the Protestant attendants — but usually religious attendance imbued the public spectacle of English and colonial executions with moral authority and sober religious import, as Randall McGowen demonstrates. ${ }^{16}$ Threlkeld's presence in court worked similarly to impart a sense of moral order to the unsettling presence of Aborigines, particularly given the fissures in law that their presence

13 L.E. Threlkeld, 'Report of the Mission to the Aborigines at Lake Macquarie, New South Wales' (1837), in Gunson, 136.

14 'R v Tommy', Supreme Court of New South Wales, 1827, Decisions of the Superior Courts of New South Wales, 1788-1899, the Division of Law, Macquarie University, http://www.law.mq.edu.au/scnsw/ Cases1827-28/html/r_v_tommy_1827.htm accessed 31 August, 2004.

15 L.E. Threlkeld, 'Reminiscences of the Aborigines of New South Wales' (1853-55), in Gunson, 97.

16 Randall McGowen, 'The Changing Face of God's Justice: The Debates over Divine and Human Punishment in Eighteenth-Century England', Criminal Justice History 9 (1988): 63-98; see also V.A C. Gatrell, The Hanging Tree: Execution and the English People, 1770-1868 (Oxford University Press, 1994) and, on execution in colonial Australia, Michael Sturma, 'Death and Ritual on the Gallows: Public Executions in the Australian Penal Colonies', OMEGA 17, no. 1 (1986): 89-100; Libby Connors, 'The Theatre of Justice: Race Relations and Capital Punishment at Moreton Bay, 1841-59', in Brisbane: The Aboriginal Presence, 1824-1860, ed. Rod Fisher (Brisbane History Group Papers, 1992), 48-57; John McGuire, 'Judicial Violence and the "Civilizing Process": Race and the Transition from Public to Private Executions in Colonial Australia', Australian Historical Studies 29, no. 111 (1998): 187-209. 
revealed, and it certainly foregrounded the importance of Christianity to the workings of English law. Arguably, though, the missionary's presence also focalised the incongruity of Aborigines as legal subjects.

When charged, Aborigines, like settlers, entered a process that inscribed them within legal discourse. The Information for each charge inaugurated a process of textual inscription and subject formation. The language of the Information is bureaucratic and formulaic: the particulars of each charge were entered by a law clerk on pre-printed forms. So, to take the instance of $R v$ Jackey in 1834, the accused is described in a routine fashion: 'Jackey an Aboriginal native of the said Colony not having the fear of God before his eyes but being moved and seduced by the instigation of the Devil ...' The language of the charge and its reading a performative speech act - dramatises the interdependence of religious and legal discourses, and immediately reveals the peculiar position of non-Christians brought before the court. If white colonials could be temporarily seduced by the devil into criminal acts then, logically, Aborigines were especially vulnerable to moral turpitude given their ignorance of Christianity. From this moment onwards, Jackey's non-Christian status proved a major hurdle to him accessing English justice. Threlkeld attended Jackey's trial as interpreter. On the one hand we can imagine Threlkeld's role as enabling Jackey to assert some limited legal rights, yet Threlkeld's role as religious representative and gatekeeper complicates any such easy assessment. Despite his lengthy evangelical career in New South Wales, Threlkeld did not baptise any Aboriginal people, even Biraban whom Threlkeld knew was educating other Aborigines about Christianity. In 1837, Judge William Westbrooke Burton concluded that - after nearly 15 years involvement with Threlkeld and after nearly a decade assisting him in the courts - Biraban was 'not yet aware of the nature of an oath'.$^{17}$

Threlkeld's role in all the cases in which he appeared as translator and ethnographic expert is thus ambiguous. Whether we understand his work as enabling Aboriginal testimony or speaking on behalf of Aborigines, as fighting for Aboriginal civil rights or as an ineffectual salve to the consciences of concerned citizens and legal personnel, Threlkeld's presence in the court (like that of Bungaree or Biraban) dramatises the conflicted position of English law in a colonial setting. Edward Broadhurst, appearing for another Aboriginal defendant in $R v$. Billy (1840), decried the impossible position in which Christian linguistic and ideological framing placed Indigenous people. Reading out 'that part of the indictment which stated that the prisoner had been excited and moved by the instigation of the devil', Broadhurst expostulated that this was 'a being whom the aborigines have no more knowledge of than they have of the

17 'R v Wombarty', Supreme Court of New South Wales, 1837, Decisions of the Superior Courts of New South Wales, 1788-1899, the Division of Law, Macquarie University, http://www.law.mq.edu.au/research/colonial_ case_law/nsw/cases/case_index/1837/r_v_wombarty/ accessed 31 August 2004. 
existence of the true God'. ${ }^{18}$ Ironically, Threlkeld was directly responsible for imparting that knowledge at precisely the same time that he regularly testified to Aboriginal ignorance of religion.

Threlkeld joined an international network of humanitarian figures who were concerned about indigenous welfare under settler colonialism, and troubled by the morality of colonisation more generally. Much recent scholarship has considered this 'imperial network' and provided imperial history with finely nuanced analysis of the multiple voices and issues at stake in the second British empire, connecting metropolitan debates with colonial concerns. ${ }^{19}$ Yet, much of this scholarship works from the Colonial Office down, or from Clapham outwards: understanding what humanitarianism looked and felt like in the colonies is rare, particularly from the antipodean perspective. Threlkeld's work across a range of humanitarian/evangelical activities provides an excellent vantage point to consider such issues, not least because he was largely ineffective in bringing about change during his career. His voluminous writings, impassioned and informed, failed to make the impact they could have, in part because of his difficult personality and fractured relationship with the LMS, but also because the colonial setting meant that he recognised contentious issues well before they registered on metropolitan agendas. In terms of legal rights for Aborigines, Threlkeld was at the vanguard of humanitarian interest. It was just at the point that the Lake Macquarie Mission lost colonial government funding that Threlkeld's representations could have had real effects.

Threlkeld's work translating for Aboriginal defendants at the New South Wales Supreme Court resonated well beyond King Street, Sydney. The reports of the Lake Macquarie Mission were sent annually to the archdeacon, the colonial secretary, and the governor, and Threlkeld often sent copies to members of his wide international correspondence network. The missionary regularly infuriated local colonial officials with his contentious claims about Aboriginal disadvantage and settler violence: to be fair, his reports were sometimes illadvised and imprecise in detail, and thus had the potential to be as damaging to genuine efforts to curtail settler aggression as they were to the reputations of

18 'R v Billy', Supreme Court of New South Wales, 1840, Decisions of the Superior Courts of New South Wales, 1788-1899, the Division of Law, Macquarie University, http://www.law.mq.edu.au/research/colonial_ case_law/nsw/cases/case_index/1840/r_v_billy/ accessed 31 August 2004.

19 See Alan Lester, Imperial Networks: Creating Identities in Nineteenth-Century South Africa and Britain (London and New York: Routledge, 2001); Alan Lester, 'Humanitarians and White Settlers in the Nineteenth Century', in Missions and Empire, ed. Norman Etherington (Oxford University Press, 2005), 64-85; Catherine Hall, Civilising Subjects: Metropole and Colony in the English Imagination, 1830-1867 (Cambridge: Polity, 2002); Anna Johnston, Missionary Writing and Empire, 1800-1860 (Cambridge University Press, 2003); Elizabeth Elbourne, Blood Ground: Colonialism, Missions, and the Context for Christianity in the Cape Colony and Britain, 1799-1852 (Montreal: McGill Queen's University Press, 2002). 
figures of colonial authority. ${ }^{20}$ Eventually, however, metropolitan sympathisers and organisations - who needed colonial evidence to support their humanitarian campaigns - eagerly sought such accounts.

On his return to London, Bannister was among the earliest metropolitan activists to call for law reform to enable Aboriginal testimony. Like Threlkeld, Bannister vociferously agitated for improving Aboriginal status through legal means. Bannister's Humane Policy (1830), which focused mainly on conflict in the Cape Colony, was explicit about the state of law in New South Wales:

The English rules of evidence, the absence of interpreters, and the ill-conduct of the people (both settlers and convicts, with special exceptions,) render it exceedingly difficult to cause the law to be put in force against murderers and other heinous wrong-doers towards the natives; and when, by any concurrence of favourable circumstances, conviction has been obtained, the government has sympathised too much with the oppressing class, and too little with the oppressed, to permit justice to have its course. ${ }^{21}$

Threlkeld's influence is clear in Bannister's advocacy for active philanthropic exertions proportionate to the scale of colonial populations. Of the new Swan River colony, he exhorts: 'It is, therefore, exceedingly to be hoped that at least an attempt will be made to save them, through the means by which at Sydney the London Missionary Society tried with considerable effort in 1826, in defiance of extraordinary obstacles'.$^{22}$

Bannister's service in New South Wales was relatively brief, and he was rarely lauded by his contemporaries for his legal work. He departed under contentious conditions, and spent most of his voyage home writing a lengthy defence of his colonial service, in part spurred by attacks in the colonial press just prior to his departure. ${ }^{23}$ Bannister was determined to establish the fact of his scrupulous treatment of Aborigines, both in terms of his legal concerns about their status and, somewhat paradoxically, his effort to suspend his humanitarian politics to allow for the appropriate conduct of his role. His key principle was 'to carry the

\footnotetext{
20 Roger Milliss expresses his frustration with Threlkeld's typically elliptical and imprecise accounts of events surrounding the Myall Creek massacre: Roger Milliss, Waterloo Creek: The Australia Day Massacre of 1838, George Gipps and the British Conquest of New South Wales (Melbourne: McPhee Gribble, 1992), 101-2. 21 Saxe Bannister, Humane Policy; Or Justice to the Aborigines of New Settlements Essential to a Due Expenditure of British Money, and to the Best Interests of Settlers, with Suggestions How to Civilise the Natives by an Improved Administration of Existing Means (1830) (London: Dawsons of Pall Mall, 1968), ccxl.

22 ibid., ccliv.

23 A document full of self-justification - reprinting much of his correspondence with Governor Darling (with whom he often quarrelled) and the colonial press - Bannister's Statements and Documents Relating to Proceedings in New South Wales, in 1824, 1825, and 1826, Intended to Support an Appeal to the King by the Attorney General of the Colony (Cape Town: printed by W. Bridekirk, 1827) bears intriguing similarity to Threlkeld's own justification to the LMS, A Statement Chiefly Relating to the Formation and Abandonment of a Mission to the Aborigines of New South Wales (Sydney: printed by R. Howe, Government Printer, 1828).
} 
law into effect wherever, and in whatever way these people [Aborigines] came into contact with us', and to encourage any effort to improve their condition. Concerned with the ethics of cross-cultural contact prior to his appointment (a "'problem" as difficult as it is interesting'), Bannister insisted that the very fact that the Colonial Office was aware that he had 'formed something like decided opinions on the subject' ensured that he was 'most cautious not to attempt setting up "theories" on it'. $^{24}$

Yet Bannister did not have a good reputation for discretion, and his preferences were evident in his correspondence with Threlkeld, for example. The two men were drawn together by scepticism about Rev. Samuel Marsden - the controversial magistrate-chaplain of the Church of England - and other prominent religious figures in New South Wales whose involvement in settler capitalism and politics dimmed their advocacy for Aboriginal affairs. The internecine tensions between evangelical and established Protestantism sharpened their critique and strengthened their shared assumptions. Bannister and Threlkeld were highly critical of the phrenological studies of Aborigines conducted by visiting medical officers on the French exploration voyages of Captain Bougainville in mid 1825, and were well aware of the dangerous potential of pseudo-science to affirm settler prejudice. Bannister sarcastically notified Threlkeld that the 'French medical gentleman has confirmed his opinion of the innate deficiency of these poor people by a careful examination of many heads'. Threlkeld suggested that, 'Perhaps the Aborigines think that there is an innate deficiency in the bulk of white men's sculls [sic] which prevents their attainment of the native language' . Dismissive of craniological studies, Threlkeld hotly asserted that his evangelical work:

lies wholly and solely with an organ that has escaped their notice namely the heart, but had they even searched and found an innate deficiency in that organ, I would then have smiled and retorted my trust is in him who has said 'A new heart will I create within them' ${ }^{25}$

This kind of deeply affective evangelical language and reasoning was familiar to both Bannister and Threlkeld; their writings resound with intense emotion, which may also account for their similar reputations for immoderate behaviour.

Bannister's Humane Policy contains trenchant critiques of imperial expansion, which reveal both his passionate humanitarian beliefs, and his refreshing lack of political caution: 'It is impossible to justify our present course of destroying every where those, whose only crime is, that they precede us in the possession of lands, which we desire to enjoy to their exclusion' ${ }^{26}$ While recognising the

24 Bannister, Statements and Documents Relating to Proceedings in New South Wales, 123

25 L.E. Threlkeld to Rev. George Burder, 10 October 1825, CWM, Australia Box 2, SOAS.

26 Bannister, Humane Policy, vi. 
work of those (like Threlkeld) who attempted to leaven imperial expansion with 'humane policy' towards indigenous communities, Bannister argued that such advocates were thwarted at every step because imperial policy and colonial governments had strongly supported opponents of humanitarianism. In New South Wales, he exhorted, 'Common right, in matters of life and death, is constantly outraged, by our neglecting the plainest principles of equity', laws that have 'for many years been known to be of the first necessity'.$^{27}$

Bannister was one of few witnesses to the British parliament's 1837-38 Select Committee on Aborigines in the British Settlements who had held colonial office in New South Wales, and his testimony drew on his personal experience across New South Wales and the Cape Colony, and his persistent research about other settler colonies. Although the committee was dominated by the turbulent state of the Cape Colony, the Australian colonies make for a repeated - if muted comparison throughout the monumental Report from the Select Committee on Aborigines (British settlements); Together with the Minutes of Evidence, Appendix and Index. Threlkeld's Lake Macquarie Mission was mentioned by several witnesses, and in written submissions, although the influence of powerful enemies such as John Dunmore Lang substantially discredited the mission. Bannister referred to the translation work Threlkeld performed (although he did not name the missionary). He advocated an empire-wide 'system of publicity' to bring colonial news to the attention of the British public and to readers in the colonies. Frequent publication of the reports of 'functionaries' would be crucial, he suggested, as would 'a very careful report of all trials of all sorts' ${ }^{28}$ Threlkeld's annual reports must have been foremost in his mind. Legal reform was his main platform: the current state of affairs not only 'constantly stopped justice' in New South Wales but also effectively 'stops the civilisation of these people at the threshold'. The failure of the justice system led to indigenous dissatisfaction and their 'impunity encourages the colonists to hold the lives of the natives cheap' ${ }^{29}$

Zoe Laidlaw compellingly describes the production of the final report of the select committee as a collaborative effort of Thomas Fowell Buxton's family, especially Anna Gurney. Late intervention by Sir George Grey (coincidentally, a keen supporter of Threlkeld's linguistic studies) resulted in considerable compromises and radical re-editing, such that the 'cuts produced a broadly imperial report, rather than the explosively Cape-focused document the

28 Report from the Select Committee on Aborigines (British Settlement) With Minutes of Evidence Appendix and Index (1837), British Parliamentary Papers, VII, 175.

29 ibid., 176. 
Buxtons had planned'. Laidlaw also notes that Bannister - a close associate of the Buxtons - was considered too indiscrete to share in the knowledge of the collaborative authorship. ${ }^{30}$

Bannister's response to the published select committee report lacked subtlety. Dedicated to Buxton as the chair of the committee, British Colonization and Coloured Tribes (1838) was intemperate in tone and frank in its disappointment. The report is internally inconsistent, Bannister insisted: 'when good, [it] is almost a dead letter; and its bad passages, grossly inconsistent wit [sic] its evidence, are of a most dangerous tendency'. Bannister was highly critical of many who gave evidence at the select committee, including Major Dundas, acting Governor Wade, and the former Cape Colony governors Benjamin D'Urban and Sir Lowry Cole. Such are the men, Bannister fulminated, 'with memories as infirm as their judgments, to whom the colonial-office is in the habit of confiding the interests of our remote possessions, and the fate of the coloured people' ${ }^{31}$

The Select Committee on Aborigines in the British Settlements and its report galvanised many. In 1838, the inaugural annual meeting of the Aborigines Protection Society (APS) in London noted that they already had correspondents sympathetic to their cause in New South Wales but sought to establish a network of 'well-informed gentlemen' resident in all the colonies to which the APS directed its attention. They requested communications, 'conveying the most specific and authentic intelligence of all circumstances connected with the Aborigines, as the most effectual means of guiding the Society to the adoption of wise and appropriate measures on their behalf' ${ }^{32}$ Threlkeld was a regular writer to the APS, in part through his earlier association with Bannister, who was involved in the establishment of the APS with Thomas Hodgkin, and served as one of its founding honorary secretaries. Threlkeld's involvement in the New South Wales Auxiliary Aborigines Protection Society (also established 1838) - where he served on the inaugural management committee - cemented the links between New South Wales and London, Threlkeld and Bannister. The APS noted their 'most lively satisfaction' at the New South Wales initiative: it was the first auxiliary society established..$^{33}$ Threlkeld's speech to the Auxiliary APS reflected on his 22 years' colonial residence, and a lengthy abstract appeared in the second annual report of the APS (1839). He retold narratives of colonial violence against Aborigines that had shocked him on arrival, and strongly restated his key principle 'that the Aborigines were entitled to protection and

30 Zoe Laidlaw, “'Aunt Anna's Report": The Buxton Women and the Aborigines Select Committee, 183537', The Journal of Imperial and Commonwealth History 32, no. 2 (2004): 18, 19; see also Laidlaw, Colonial Connections, 1815-45: Patronage, the Information Revolution and Colonial Government (Manchester and New York: Manchester University Press, 2005).

31 Saxe Bannister, British Colonization and Coloured Tribes (London: William Ball, 1838), 253, 244.

32 First Annual Meeting of the Aborigines Protection Society (London: Aborigines Protection Society, 1838), 12-13.

33 Second Annual Report of the Aborigines Protection Society (London: Aborigines Protection Society, 1839), 25. 
compensation from those who had forcibly deprived them of their patrimony' ${ }^{34}$ The APS regularly published Threlkeld's Annual Report of the Lake Macquarie Mission, and other correspondence, in their reports and extracts from their papers and proceedings. Reform of Aboriginal evidence laws was one of the first and most important goals for the APS: Threlkeld's experience made him a significant informant for the London committee.

The late 1830s saw an acceleration of Threlkeld's concern with court processes and Aboriginal rights. His 1837 annual report exploded with frustration. It was, Threlkeld wrote, 'a mere Legal Fiction' to claim that Aborigines were 'subject to and under the protection of British Law' when their evidence could not be heard in court. ' $[\mathrm{T}]$ he strictness of the administration of the law becomes the height of injustice to all', he posited, and cast this as a moral failing not just of the colony but of Britain. The value of Aboriginal land, he reminded his readers, 'fills the coffers of our Exchequer with Gold, exalts Britain amongst the nations'. Britons accrued a debt by establishing colonies based on 'the destruction of the native inhabitants thereof, and thus presents a powerful claim to the tender sympathies of our Christian Charities'. Surely, in 'this age of Intellect', he pleaded, the British constitution could be amended to take account of circumstances that it could never have foreseen: if not, the consequence would be that 'year after year, the Aborigines [would] be frittered away from the land by private vengeance for injuries publicly sustained'. Generally, Threlkeld suggested, there was 'a kindly feeling, a friendly disposition manifested towards the Blacks by the Colonists', but the 'private vengeance of injured Europeans' would, he warned, with steady purpose 'surely, secretly, and speedily annihilate the Aborigines from the face of this Land'. ${ }^{35}$ Threlkeld's provocative warning about the effects of neglecting Aboriginal testimony joined other more sober efforts to engender change. ${ }^{36}$ The APS extracted from the 1837 report Threlkeld's explosive comments about the 'Legal Fiction' of colonial law, and his story about Wombarty's trial, for reprinting in their Extracts from Papers and Proceedings (1839).

Other personal connections linked Threlkeld to metropolitan debates. Burton had requested a copy of Threlkeld's personal records as part of the evidence he collected to take back to Britain on his two-year leave in 1839. Burton had been the presiding judge at five of the 1835-36 cases at which Threlkeld had appeared as translator (and also at the libel trial Threlkeld brought against John Dunmore Lang in 1836); in 1838, he sentenced the seven settlers convicted of the Myall Creek massacre. Threlkeld was keenly interested in the Myall Creek trials, as they brought to a head many of the rumours and evidence about settler

\footnotetext{
34 ibid., 15.

35 Threlkeld, 'Report 1837', 136.

36 See Nancy Wright's excellent analysis of the Aboriginal Evidence acts. Nancy E. Wright, 'The Problem of Aboriginal Evidence in Early Colonial New South Wales', in Law, History, Colonialism: The Reach of Empire, eds, Diane Kirkby and Catharine Coleborne (Manchester University Press, 2001), 140-55.
} 
aggression to which he had long been privy. During the long process of copying his records, Threlkeld wrote to Burton with further evidence about violence taking place on the Liverpool Plains and seeking his advocacy with Governor George Gipps:

such things ought to be made known to his Excellency that he may be enabled to judge betwixt man and man in the unequal warfare with the Blacks, and I could not rest satisfied to let the matter rest until my annual report to the Governor. ${ }^{37}$

Threlkeld's careful copperplate transcription of his lengthy Memoranda Selected from 'Twenty Four Years of Missionary Engagements in the South Sea Islands and Australia' bears a respectful and personal autograph for Burton. Roger Milliss notes that Burton failed to produce the formal submission about the treatment of Aborigines - to be titled 'Memoranda of Outrages against the Aborigines' - that he had intended, but that his notes towards the project contain much material drawn directly from Threlkeld's Memoranda and his 1837 and 1838 reports. ${ }^{38}$ Burton carefully assessed Threlkeld's testimony about mass slaughter of Aborigines and the culpability of police and military officials (Sergeant Temple and Major James Nunn, in two separate instances that Threlkeld described in his 1837 report). The missionary's frank and fulsome explanations to Burton's subsequent queries indicate a considerable level of trust in Burton (for many years, Threlkeld had been very circumspect about what evidence he made public). Comments in personal correspondence between the two men also suggest a personal connection.

Burton published The State of Religion and Education in New South Wales (1840) during his short absence from New South Wales, and his book bears some evidence of Threlkeld's perspectives, amongst many others. His characterisation of Australia as 'a great Moral Wilderness' ${ }^{39}$ recalls Threlkeld's dire description of the poverty of the antipodean religious mission in 1827: 'all dry, dry, very dry scattered bones, in the midst of a waste howling wilderness'. ${ }^{40}$ Burton condemns the absence of religion in outlying areas, and specifically situates this as a causal factor for the Myall Creek atrocities: these crimes, 'of almost unheard

37 L.E. Threlkeld to Judge Burton, 20 July 1838, Original Documents on Aborigines and Law, 1797-1840 (Sydney: The Centre for Comparative Law, History and Governance of Macquarie University, and State Records NSW), http://www.law.mq.edu.au/scnsw/Correspondence/74.htm see also Gunson, 267-68.

38 Milliss, 612.

39 William Westbrooke Burton, The State of Religion and Education in New South Wales (London: J. Cross, 1840), 310 .

40 L.E. Threlkeld, A Statement Chiefly Relating to the Formation and Abandonment of a Mission to the Aborigines of New South Wales; Addressed to the Serious Consideration of the Directors of the London Missionary Society (Sydney: R. Howe, Government Printer, 1828), 29. See Meredith Lake, 'Protestant Christianity and the Colonial Environment: Australia as a Wilderness in the 1830s and 1840s', Journal of Australian Colonial History 11 (2009): 21-44, for an analysis of the trope of wilderness for Protestant clergy writing about Australia, although Threlkeld's usage predates her examples. 
of depravity', were the 'consequences of Men living unawed by, because far out of the reach of the laws, and uninfluenced by Religion' ${ }^{41}$ Interestingly, Burton also makes clear his contempt for John Dunmore Lang, Threlkeld's longterm adversary, and the 'Internal Animosities' in which Lang and his Colonist newspaper revelled. ${ }^{42}$

Those internal animosities motivated many of the mixed messages that emerged from colonial New South Wales. Ultimately they ensured that Threlkeld's evidence was itself something of a dead letter at the time of the select committee. Lang had an ongoing feud with Threlkeld and a predilection for undermining religious competitors, so his written testimony to the committee repeated his libellous comments that Threlkeld had mismanaged the Lake Macquarie Mission from the outset and, consequently, little had been achieved in the decade since its formation. Marsden was so exasperated with Threlkeld's independence and quarrelsome behaviour that his submission made no mention of missions in New South Wales at all. Instead, as is typical of Marsden's abrupt dismissal of Australian Aborigines, his letter resonates with indignation on behalf of the Māori and exclusively details his humanitarian efforts in New Zealand. Only the LMS missionary John Williams (soon to depart for Erromanga where he would be killed by islanders) lauded Threlkeld's active employment amongst Aborigines.

By 1840, Threlkeld's annual reports were receiving the publicity that Bannister had advocated in the select committee. One phrase in particular resonated across many different media in colonial and metropolitan sites: 'Christian laws will hang the aborigines for violence done to Christians, but Christian laws will not protect them from the aggressions of nominal Christians, because aborigines must give evidence only upon oath'. ${ }^{43}$ Yet 1841 saw the end of colonial government funding for the Lake Macquarie Mission.

Threlkeld's involvement in legal settings implicates him in the messy, inchoate operations of colonial governmentality, even while his work was motivated by a desire to force the system to confront its own limitations, as in the case of Aboriginal testimony. Threlkeld's legal representations were bound with the efforts of the nascent settler state to govern its most challenging subjects, even though attempts at control were frequently unstable and insecure. Connecting local Supreme Court trials with the broader work of British parliamentary committees emphasises the ways in which colonial knowledge moved across

\footnotetext{
41 Burton, State of Religion, 279.

42 See ibid., Appendix, cxviii.

43 The phrase originated in Threlkeld's 1840 Report: 'Report of the Mission to the Aborigines at Lake Macquarie, New South Wales' (1837), in Gunson, 166. It was reprinted, with various abridgements and commentary, by the Sydney Herald, Sydney Gazette, in the APS Extracts, and by the London Quakers' Report from the Meeting for Sufferings.
} 
geographical boundaries while also providing the motor for governing both locally and trans-imperially. Threlkeld himself linked specific instances of colonial law to broader philosophical questions about the relationship between European and colonial peoples, between imperial policy and colonial governance. He brought to bear his ethnographic, evangelical knowledge upon issues germane to constitutions and sovereignty. Yet, the complexity of his own writing, and the awkward slippage between his good intentions and the consequences of his representations, provide evidence that continues to trouble simple narratives about Australia's colonial past. 